\title{
Study on the strategies of developing modern logistics in railway freight industry
}

\author{
Zhang Ailing ${ }^{1, a}$ \\ Beijing Jiaotong University, Beijing 100000, China \\ a973827134@qq.com
}

Keywords: Railway Freight, Modern Logistics, Development Strategy

\begin{abstract}
With the development of market economy,the rise of the various modes of transportation, the share of railway transportation in the market showed a declining trend,under the traditional transportation mode, railway freight transportation has been unable to obtain substantial benefits, in the case,it is necessary for railway freight industry to develop modern logistics in Chinese transportation market.Therefore,it is important for railway freight to develop modern logistics.This paper based on the development of rail freight industry in three specific modes of modern logistics: constructing the virtual alliance of railway logistics, establishing regional logistics network, and establishing the national logistics network. Application of fuzzy evaluation method is to railway freight develops modern logistics to select specific path of empirical analysis,taking Beijing Railway Bureau Fengtai Freight Center for instance,by constructing the evaluation index system selection for railway freight industry developing modern logistics strategy provides a quantitative basis.
\end{abstract}

\section{Specific problems existing in rail freight transport}

The logistics service of the existing freight station is the simple transport, covering the simple storage and other simple services. the traditional logistics services, such as the shortcomings of the main include:

(1) large quantities of goods occupy the main position;

(2) the competitiveness of the goods loading and unloading, and storage is not strong; the goods loading and unloading, and storage aspects of competitiveness is not strong;

(3) the various logistics services are isolated and scattered;

(4) limited scope of logistics services.

\section{The choice of modern logistics development strategy of railway freight transportation industry}

In this paper according to the three kinds of logistics development mode, namely the construction of railway logistics alliance, Regional Railway Group and the National Railway Group. Firstly, we build evaluation index system of modern logistics development model of railway freight, and use the method of analytic hierarchy process the corresponding weight value, then using fuzzy comprehensive evaluation method to select the developing mode that the railway freight enterprises to develop modern logistics.

Combined with the current situation of railway freight transportation development, the evaluation index system of modern logistics development strategy of railway freight as shown in figure 1. 


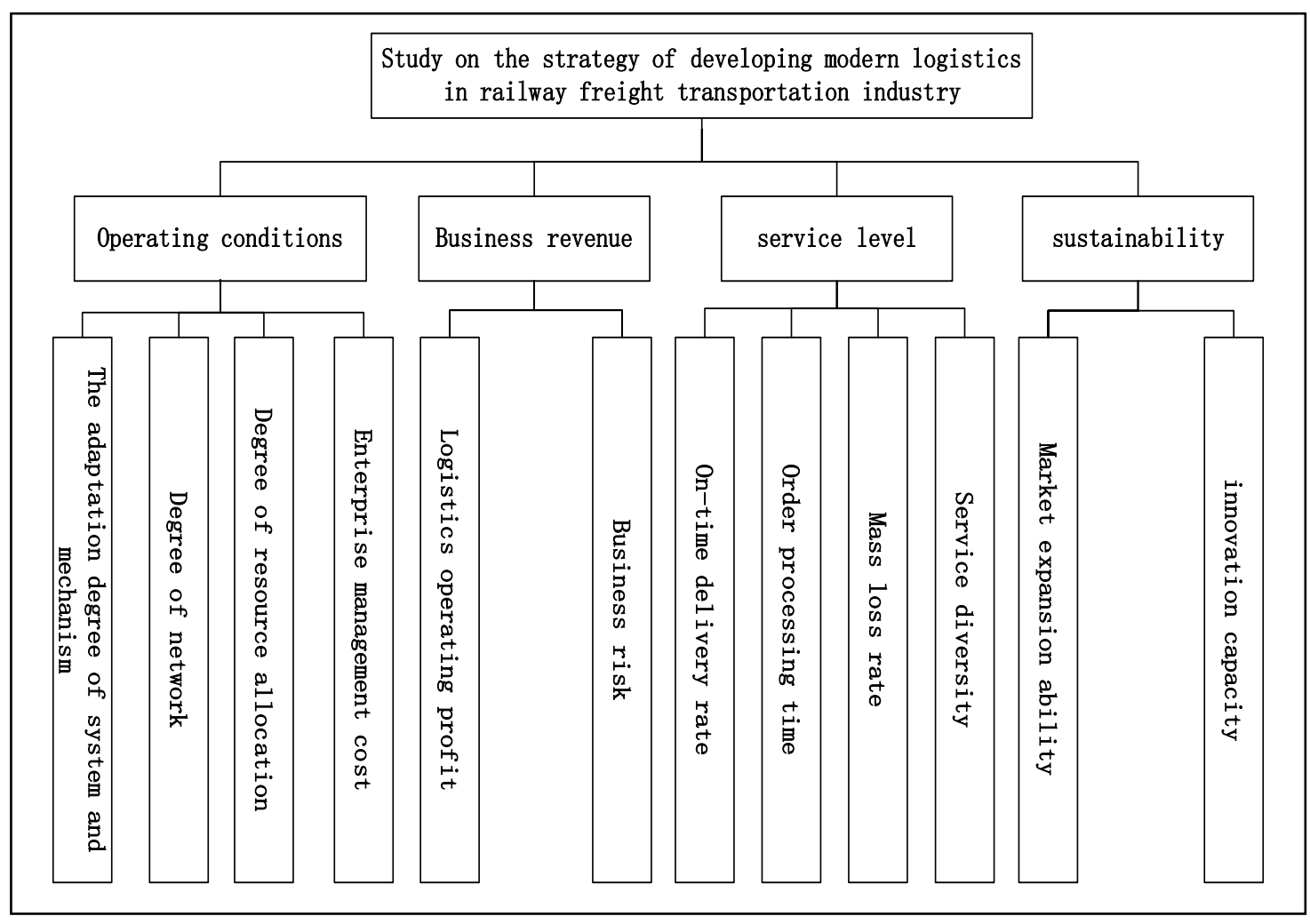

Figure 1 the evaluation index system of modern logistics development strategy of railway freight

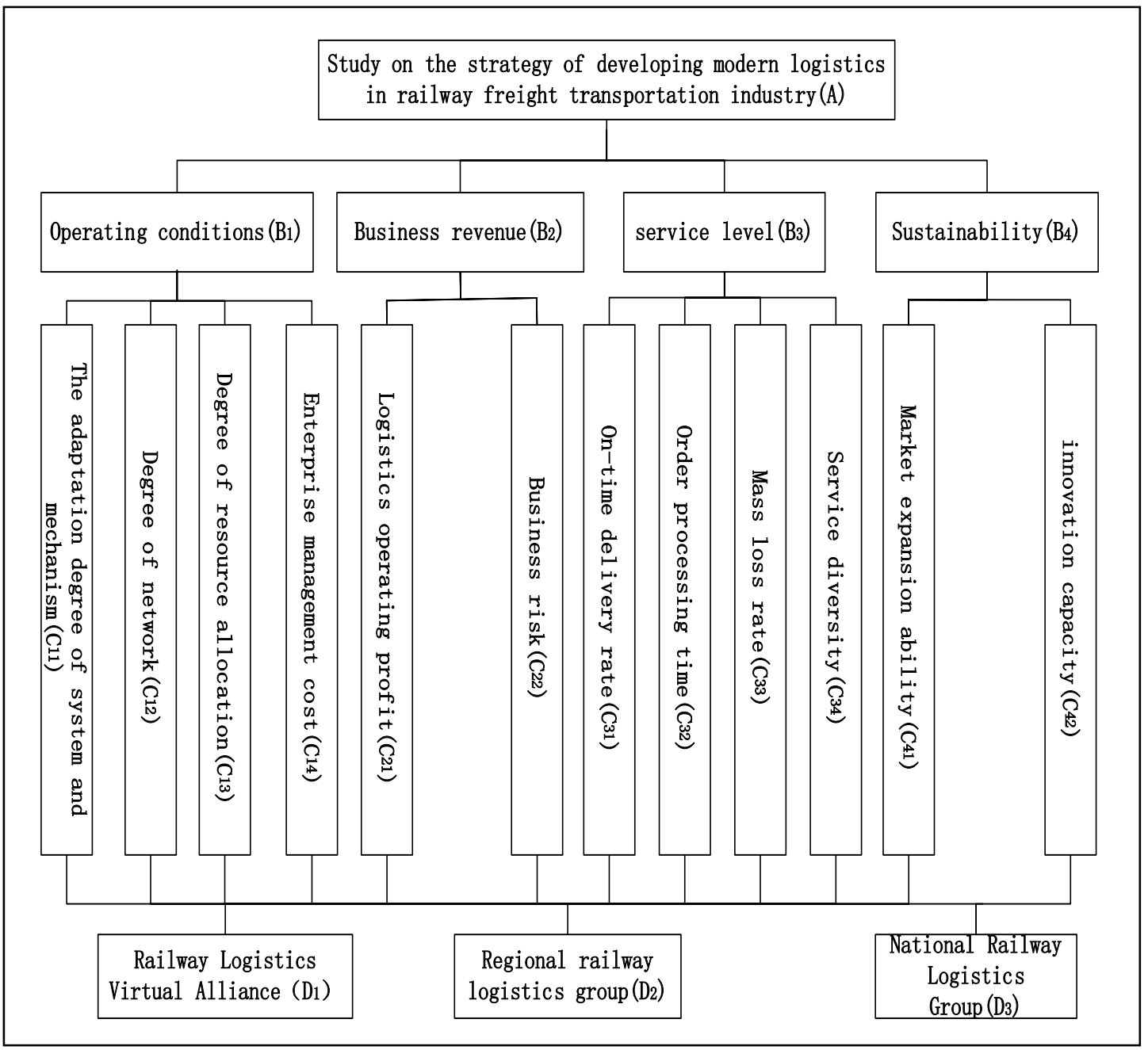

Figure 2 the railway freight industry modern logistics development mode selection hierarchy diagram 


\section{Case analysis: the development of modern logistics strategy selection of Fengtai Railway freight center}

Fengtai freight center logistics status quo analysis. Beijing Fengtai Railway Bureau Freight Center is formed by Beijing Railway Bureau in May 2013 27, through integrating transportation, handling, measurement and other departments of the Zhangjiakou Railway depot, original Shijingshan train depot and Fengtai West Station.. Center mainly includes nine business department, namely kongjiazhuang, Zhangjiakou, Xuanhua, Xiahuayuan, Shacheng, Fengtai West, Laiyuan, Liangezhuang and Sanjiadian. Then set up 38 outlets, each network is mainly responsible for Beijing, Hebei, Shanxi's coal transport work.

Strategy evaluation. According to the strategy of the development of modern logistics and the evaluation index system of the railway freight industry, the main process of strategy selection is as follows:

(1) According to the evaluation index system established above, to make the railway freight industry logistics model selection hierarchy chart, as shown in figure 2.

(2) The evaluation index system was evaluated by the 1-9 method of AHP method. In order to get a scientific score, we consulted the relevant experts of Fengtai Railway freight center.

(3) Calculating judgment matrix.

The relative weight value is calculated by the judgment matrix of each layer, and carries on the consistency check. Consistency index: $\mathrm{CI}=\frac{\lambda \max -n}{n-1} \quad, \quad \lambda \max =\sum_{i} \frac{(A W)_{i}}{\omega_{i}}$.

The concrete calculating process and results are shown in Table 1.

Table 1 calculating table

\begin{tabular}{|c|c|c|c|c|c|c|c|}
\hline \multirow{5}{*}{ A-B } & $\mathrm{A}$ & $\mathrm{B}_{1}$ & $\mathrm{~B}_{2}$ & $\mathrm{~B}_{3}$ & $\mathrm{~B}_{4}$ & $\omega_{A}$ & \multirow{5}{*}{$\begin{array}{l}\lambda \text { max }=4.262 \\
\mathrm{CI}=0.087 \\
\mathrm{CR}=0.098\end{array}$} \\
\hline & $\mathrm{B}_{1}$ & 1 & 6 & 5 & 8 & 0.6169 & \\
\hline & $\mathrm{B}_{2}$ & $1 / 6$ & 1 & 3 & 6 & 0.2284 & \\
\hline & $\mathrm{B}_{3}$ & $1 / 5$ & $1 / 3$ & 1 & 2 & 0.1004 & \\
\hline & $\mathrm{B}_{4}$ & $1 / 8$ & $1 / 6$ & $1 / 2$ & 1 & 0.0544 & \\
\hline \multirow{5}{*}{$\mathrm{B}_{1}-\mathrm{C}$} & $\mathrm{B}_{1}$ & $\mathrm{C}_{11}$ & $\mathrm{C}_{12}$ & $\mathrm{C}_{13}$ & $\mathrm{C}_{14}$ & $\omega_{\mathrm{B} 1}$ & \multirow{5}{*}{$\begin{array}{c}\lambda \text { max }=4.147 \\
\mathrm{CI}=0.049 \\
\mathrm{CR}=0.055\end{array}$} \\
\hline & $\mathrm{C}_{11}$ & 1 & 6 & 4 & 2 & 0.4398 & \\
\hline & $\mathrm{C}_{12}$ & $1 / 6$ & 1 & $1 / 3$ & $1 / 4$ & 0.0803 & \\
\hline & $\mathrm{C}_{13}$ & $1 / 4$ & 3 & 1 & $1 / 3$ & 0.1548 & \\
\hline & $\mathrm{C}_{14}$ & $1 / 2$ & 4 & 3 & 1 & 0.3251 & \\
\hline \multirow[b]{3}{*}{$\mathrm{B}_{2}-\mathrm{C}$} & $\mathrm{B}_{2}$ & $\mathrm{C}_{21}$ & $\mathrm{C}_{22}$ & & & $\omega_{\mathrm{B} 2}$ & \multirow{3}{*}{$\begin{array}{c}\lambda_{\max }=2 \\
\mathrm{CI}=0 \\
\mathrm{CR}=0\end{array}$} \\
\hline & $\mathrm{C}_{21}$ & 1 & 3 & & & 0.75 & \\
\hline & $\mathrm{C}_{22}$ & $1 / 3$ & 1 & & & 0.25 & \\
\hline \multirow{5}{*}{$\mathrm{B}_{3}-\mathrm{C}$} & $\mathrm{B}_{3}$ & $\mathrm{C}_{31}$ & $\mathrm{C}_{32}$ & $\mathrm{C}_{33}$ & $\mathrm{C}_{34}$ & $\omega_{\mathrm{B} 3}$ & \multirow{5}{*}{$\begin{array}{c}\lambda \max =4.392 \\
\mathrm{CI}=0.131 \\
\mathrm{CR}=0.147\end{array}$} \\
\hline & $\mathrm{C}_{31}$ & 1 & $1 / 6$ & 3 & 3 & 0.2109 & \\
\hline & $\mathrm{C}_{32}$ & 6 & 1 & 5 & 4 & 0.5745 & \\
\hline & $\mathrm{C}_{33}$ & $1 / 3$ & $1 / 5$ & 1 & $1 / 3$ & 0.0726 & \\
\hline & $\mathrm{C}_{34}$ & $1 / 3$ & $1 / 4$ & 3 & 1 & 0.1420 & \\
\hline \multirow{3}{*}{$\mathrm{B}_{4}-\mathrm{C}$} & $\mathrm{B}_{3}$ & $\mathrm{C}_{41}$ & $\mathrm{C}_{42}$ & & & $\omega_{\mathrm{B} 4}$ & \multirow{3}{*}{$\begin{aligned} \lambda_{\text {max }} & =2 \\
\mathrm{CI} & =0 \\
\mathrm{CR} & =0\end{aligned}$} \\
\hline & $\mathrm{C}_{41}$ & 1 & 3 & & & 0.75 & \\
\hline & $\mathrm{C}_{42}$ & $1 / 3$ & 1 & & & 0.25 & \\
\hline
\end{tabular}

After adjustment, CI and CR of all levels are less than 0.1, so the consistency of the test is passed. 
(4)Overall hierarchial sequencing. According to the calculating formula of the comprehensive importance, the weight value of each first-class index is calculated with respecting to the total target.

The calculating formula of the comprehensive importance:

Importance of scheme C1 (weight) $=0.3229$

Importance of scheme C2 (weight) $=0.5198$

Importance of scheme C3(weight) $=0.2763$

Importance of scheme C4(weight) $=0.5198$

Weight calculating results of evaluating Index of railway freight industry logistics mode are shown in Table 2.

Table 2 Evaluation index weight calculating results of modern logistics mode of railway freight transportation industry

\begin{tabular}{|c|c|c|c|c|}
\hline First class indicator & Weight & Second class indicator & Weight & Total weight \\
\hline \multirow{4}{*}{$\begin{array}{c}\text { Operating } \\
\text { conditions }\left(\mathrm{B}_{1}\right)\end{array}$} & \multirow{4}{*}{0.6169} & $\begin{array}{c}\text { The adaptation degree of system } \\
\text { and mechanism }\left(\mathrm{C}_{11}\right)\end{array}$ & 0.4398 & 0.2713 \\
\hline & & Degree of network $\left(\mathrm{C}_{12}\right)$ & 0.0803 & 0.0495 \\
\hline & & $\begin{array}{l}\text { Enterprise management } \\
\operatorname{cost}\left(\mathrm{C}_{14}\right)\end{array}$ & 0.1548 & 0.0955 \\
\hline & & $\begin{array}{l}\text { Degree of resource } \\
\text { allocation }\left(C_{13}\right)\end{array}$ & 0.3251 & 0.2006 \\
\hline \multirow{2}{*}{ Business revenue $\left(B_{2}\right)$} & \multirow{2}{*}{0.2284} & Logistics operating profit $\left(\mathrm{C}_{21}\right)$ & 0.75 & 0.1713 \\
\hline & & Business risk $\left(\mathrm{C}_{22}\right)$ & 0.25 & 0.0571 \\
\hline \multirow{4}{*}{ Service level( $\left.B_{3}\right)$} & \multirow{4}{*}{0.1004} & On-time delivery rate $\left(\mathrm{C}_{31}\right)$ & 0.2109 & 0.0212 \\
\hline & & Order processing time $\left(\mathrm{C}_{32}\right)$ & 0.5745 & 0.0577 \\
\hline & & Mass loss rate $\left(\mathrm{C}_{33}\right)$ & 0.0726 & 0.0073 \\
\hline & & Service diversity $\left(\mathrm{C}_{34}\right)$ & 0.1420 & 0.0143 \\
\hline \multirow{2}{*}{ Sustainability $\left(\mathrm{B}_{4}\right)$} & \multirow{2}{*}{0.0544} & Market expansion ability $\left(\mathrm{C}_{41}\right)$ & 0.75 & 0.0408 \\
\hline & & innovation capacity $\left(\mathrm{C}_{42}\right)$ & 0.25 & 0.0136 \\
\hline
\end{tabular}

Finally, we get the weight value of each second class index relative to the research question. $\mathrm{W}=(0.2713,0.0495,0.0955,0.2006,0.1713,0.0571,0.0212,0.0577,0.0073,0.0143,0.0408,0.01$ 36)

(5) In order to establish fuzzy comprehensive evaluation matrix. Using fuzzy comprehensive evaluation method, Invite experts of fengtai cargo center to rate for the 12 grade evaluation index on the basis of three development modes that railway logistics enterprises expand modern logistics.

The scores of each evaluation index are obtained by the expert, and the fuzzy comprehensive evaluation matrix is established.

$$
\mathrm{R}=\left[\begin{array}{lll}
8 & 4 & 2 \\
7 & 5 & 5 \\
5 & 5 & 5 \\
3 & 5 & 4 \\
5 & 6 & 5 \\
4 & 5 & 5 \\
5 & 5 & 6 \\
5 & 6 & 5 \\
4 & 5 & 4 \\
7 & 5 & 5 \\
5 & 5 & 5 \\
6 & 5 & 4
\end{array}\right]
$$


The final comprehensive evaluating matrix is established by the weight matrix and the single factor evaluating matrix:

$\mathrm{Q}=\mathrm{PR}==(5.4689,4.9587,3.9868)$

The calculation results show that the suitability of constructing railways Logistics Virtual Alliance, setting up a regional logistics group and building a national railway Railway Logistics Group's were 5.4689, 4.9587, 3.9868.

Thus, in the current operating mechanism, the optimal model that Fengtai freight station develop modern logistics is constructing virtual logistics alliance. This is related to the environmental factors, and other factors, such as the financial conditions, technical conditions and other factors. In the rapid development of the economy, in order to achieve the overall integration, large-scale and systematic operation, Rail freight will gradually develop into a Group enterprise.

\section{Summary}

The development of modern logistics in railway freight transportation is a part of freight transportation reform. We can see that achieving the modern logistics development across the Bureau still have some limitations through analysis of the three models.For example, environmental factors such as system conditions, and other factors, such as the funding conditions, technical conditions and other factors.

This article has carried on the discussion and the research mainly from the macroscopic aspect for the mode of railway freight industry developing modern logistics. Provide qualitative and quantitative support for railway freight developing modern logistics. We hope that railway freight developing modern logistics can better meet the needs of social development, and promote economic development.

\section{Reference}

[1] Christopher Martin. Marketing Logistics[M]. Oxford: Alden press Ltd, 1997.

[2] Arch W. Shaw. Some Problems In Market Distribution [M]. Harvard university press, 1915.

[3] Bask. to Quebec City[M]. Ottawa: The Meamillan Company of Cannada. Limited, 2001: 39-55.

[4] Parsons-clough Harbour.Existing corridor conditions and opportunities-I-87multimodal corrid orstudy[R]. New York:New York State Department of Transportation, 2004.

[5] RohitBhatnagarl. Third party logistics services a Singapoe perspective[J]. International Journal of Physical Distribution\&Logistics Management, 1999 (29) 569-587.

[6] Chicheng,Qin Siping,Wang Xin.Thoughts on the development of modern logistics in railway freight transportation in China[J]. Ha Erbin: Logistics technology, 2008 (4).

[7] Yu Wenjin,Liu Kai. Analysis on the mode of railway developing modern logistics center [J]. Beijing: Railway Transport and Economy, 2003 (5) : 3-5.

[8] WangJian, Introduction to modern logistics[M]. Beijing: Peiking University pres, 2005.

[9] Chen Gang . Discussion on logistics management modes of transportation enterprises[J]. Wuhan: Journal of Wuhan University of Technology , 2004 (2).

[10] Wang Changqiong.Logistics system engineering[M]. Beijing: Higher Education Press , 2007. 